J. Perinat. Med.

1 (1973) 125

\section{Ambulance with intensive care facilities for the transport of infants at risk}

\author{
H.-D. Frank, L. Ballowitz, H. Schachinger \\ From the Children's Clinic of the Free University of Berlin \\ Kaiserin Auguste Victoria Haus
}

Received September 18, 1972. Accepted October 24, 1972.
1. The significance of good transportation for newborns, and the way to its realization

The present report deals with the results of a two year development program which had as its goal the improvement of transportation facilities for the infant at risk, as well as minimization of the risk of transport for all participants.

Pediatric or neonatal intensive care units within immediate proximity of delivery rooms provide the ideal conditions for resuscitation and continuation of intensive care of the asphyxiated newborn, according to v. LoEweNICH and BERg [3]. Nevertheless, considerable distance frequently separates the two, making it necessary to refer to a neonatal center those newborns whose vital functions remain in question after the primary resuscitation. A well-organized transport system for these critically ill newborns is seldom available, even though the need is obvious from an obstetrical as well as a pediatric standpoint. Unfortunately, as so often happens even today, the continuity of care in monitoring and treatment is interrupted by hasty, illprepared transport to the children's clinic in poorly heated transport incubators. If therapeutic procedures are eventually required during transport, the threat of hypothermia with associated hypoxia and acidosis becomes even greater. In this manner, initially successful resuscitative efforts can later be brought to naught.

Some practical experience on how to handle this situation has been gathered by others. Here in Germany, the transport unit of MAus [4] from Heidelberg may be mentioned. It combines an incubator, suction pump, respirator and oxygen tank in a custom-built clothes-basket arrangement with observations ports. ScerwerkarT [5] from Wuppertal, has also developed a permanently fixed transport unit for newborns. A much more ambitious undertaking with

\section{Curriculum vitae}

H.-D. FRANK: born in Marburg/Labn (Germany) 1939. Medical student at the Saarland University in Saarbriicken and at the Free University of Berlin. 1965 final medical examination. Internship for 5 months in the Children's Clinic of the Free University of Berlin (Kaiserin Auguste Victoria Haus) and later on working in rotation at several bospitals in the German Federal Republic. 1968 State

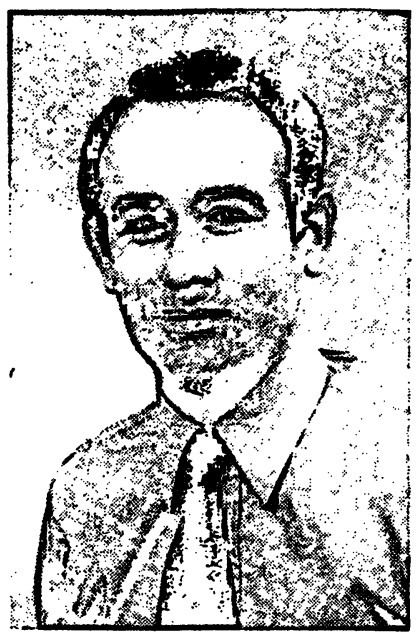

Examination and Doctoral thesis. Since 1969 Resident at the Children's Clinic of the Free University of Berlin. At present Senior Resident on the intensive care ward.

specially equipped ambulance was displayed by BARRIE [1] at the Second European Congress of Perinatal Medicine in London in 1970. Mobile neonatal intensive care units developed largely by Silverman [6] are in use in New York and San Francisco.

Whereas the German models represent primarily referral units for newborn transport from maternity hospitals to children's clinics, the mobile units of BARRIE and SILVERMAN are intended to function more as complete newborn intensive care units. They carry with them a full complement of equipment and personnel, in specially outfited vans, traveling to the respective obstetrical clinic, and the pediatricians can take part in resuscitation.

As pediatricians, we are naturally inclined to favor the second model, since in our opinion precise understanding of the course of the delivery, the method and effectiveness of the resuscitation efforts and the behavior of the child during the transport is of the utmost importance, filling in the gaps in information and heightening the degree of watchfulness over the infant at risk. 
2. Characteristics of a functional emergency service

The essential components of a neonatal emergency service as we see it, are outlined in Tab. I.

Tab. I. Structure of a neonatal emergency service.

\begin{tabular}{|c|c|c|}
\hline $\begin{array}{l}\text { A. Transport } \\
\text { Incubator }\end{array}$ & $\begin{array}{l}\text { B. Means of } \\
\text { Transport }\end{array}$ & $\begin{array}{l}\text { C. Transport } \\
\text { Personnel }\end{array}$ \\
\hline $\begin{array}{l}\text { 1. Complete } \\
\text { Resuscitation }\end{array}$ & $\begin{array}{l}\text { 1. Spacious } \\
\text { Emergency } \\
\text { Vehicle }\end{array}$ & $\begin{array}{l}\text { 1. } 24 \text { hour Peri- } \\
\text { natal Emer- } \\
\text { gency Service }\end{array}$ \\
\hline $\begin{array}{l}\text { 2. Continuous } \\
\text { Monitoring } \\
\text { and Treatment }\end{array}$ & $\begin{array}{l}\text { 2. Internal and } \\
\text { External } \\
\text { Safety in } \\
\text { Transit }\end{array}$ & $\begin{array}{l}\text { 2. Experience in } \\
\text { Neonatal } \\
\text { Resuscitation }\end{array}$ \\
\hline $\begin{array}{l}\text { 3: Independent } \\
\text { Power Supply }\end{array}$ & $\begin{array}{l}\text { 3. Power } \\
\text { Reserves }\end{array}$ & $\begin{array}{l}\text { 3. Technical } \\
\text { Skill }\end{array}$ \\
\hline
\end{tabular}

\subsection{Transport incubator}

\subsubsection{The complete resuscitation unit (Fig. 1)}

The main component of the unit is the model 1300 newborn incubator from DraEger, Lübeck. It has proven well-suited to observation and care of seriously ill infants. Its application as a transport incubator was first witnessed in the intensive care unit of the Düsseldorf Children's Clinic, where for many years it has been utilized for transporting babies from one area of the ex- pansive grounds of the clinic to the other. It is permanently mounted on a carriage of steel pipe construction with pneumatic tires, and can be pushed by hand from one duty station to another. This mobile resuscitation unit was constructed in accordance with plans of LEMBURG and STEMmanN [2].

In the Berlin model (Fig. 1), the most important elements used for acute resuscitation as well as for more prolonged treatment and monitoring are arranged around the incubator so as to be always within view and reach of the physician. These include the suction apparatus with mucous trap to clear and keep open the upper airway, the oxygen flow regulator with humidifier, an I. V. stand for the infusion solutions and a respirator for mechanical ventilation (BIRD-MARK 8).

\subsubsection{Continuous=monitoring and treatment:} Often the difficulties of neonatal adaptation for the asphyxiated infant are not definitely resolved at the time of successful resuscitation in the delivery room. Frequently, a worsening of the infant's condition suddenly takes place, and this may occur during transport. For this reason, continuous monitoring of vital functions is of outstanding importance. When one considers the usual transport "cage" used in Germany today and its precarious position in a speeding

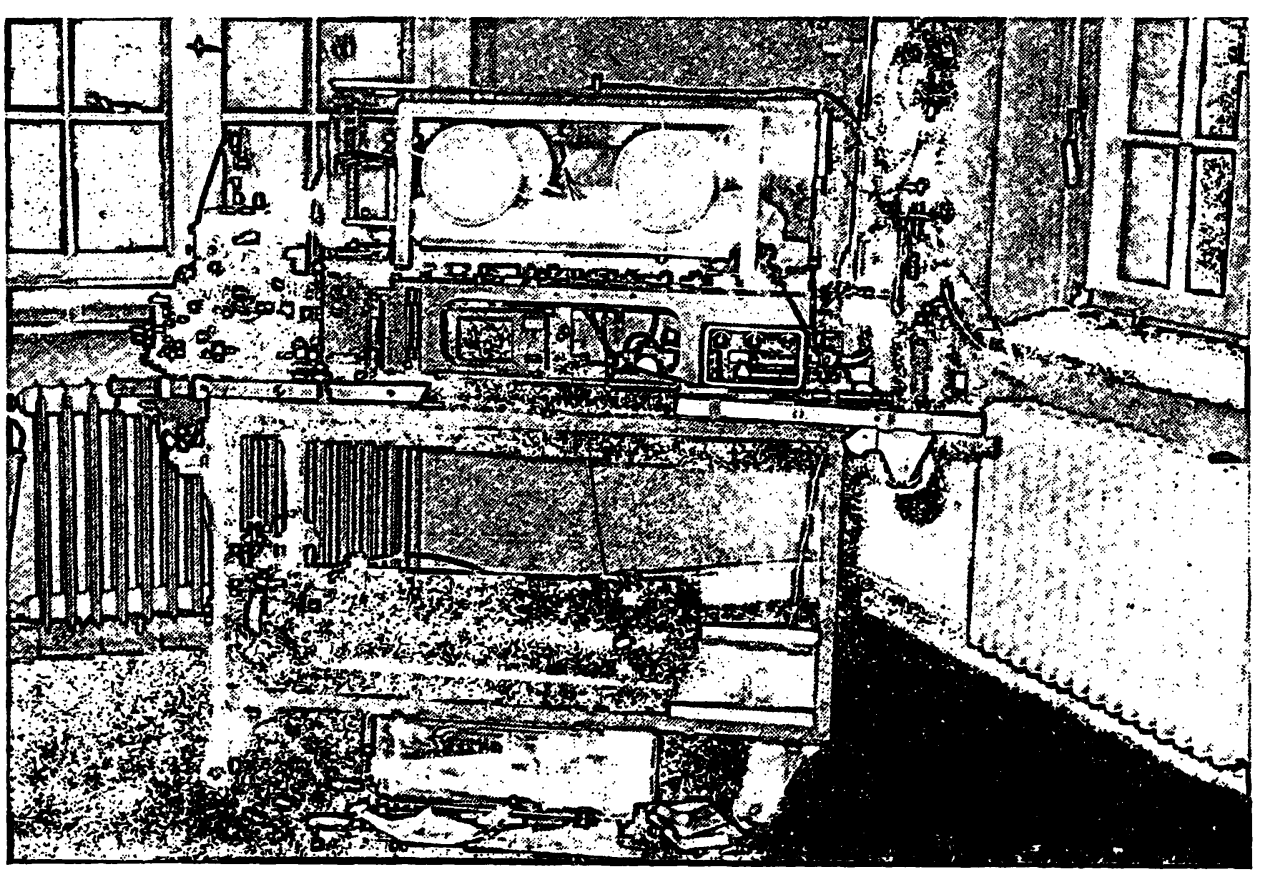

Fig. 1. Carriage and complete transport resuscitation unit in the Children's Clinic 
Fig. 3. Rolling in the resuscitation unit on the U-profile frame of the lift table.

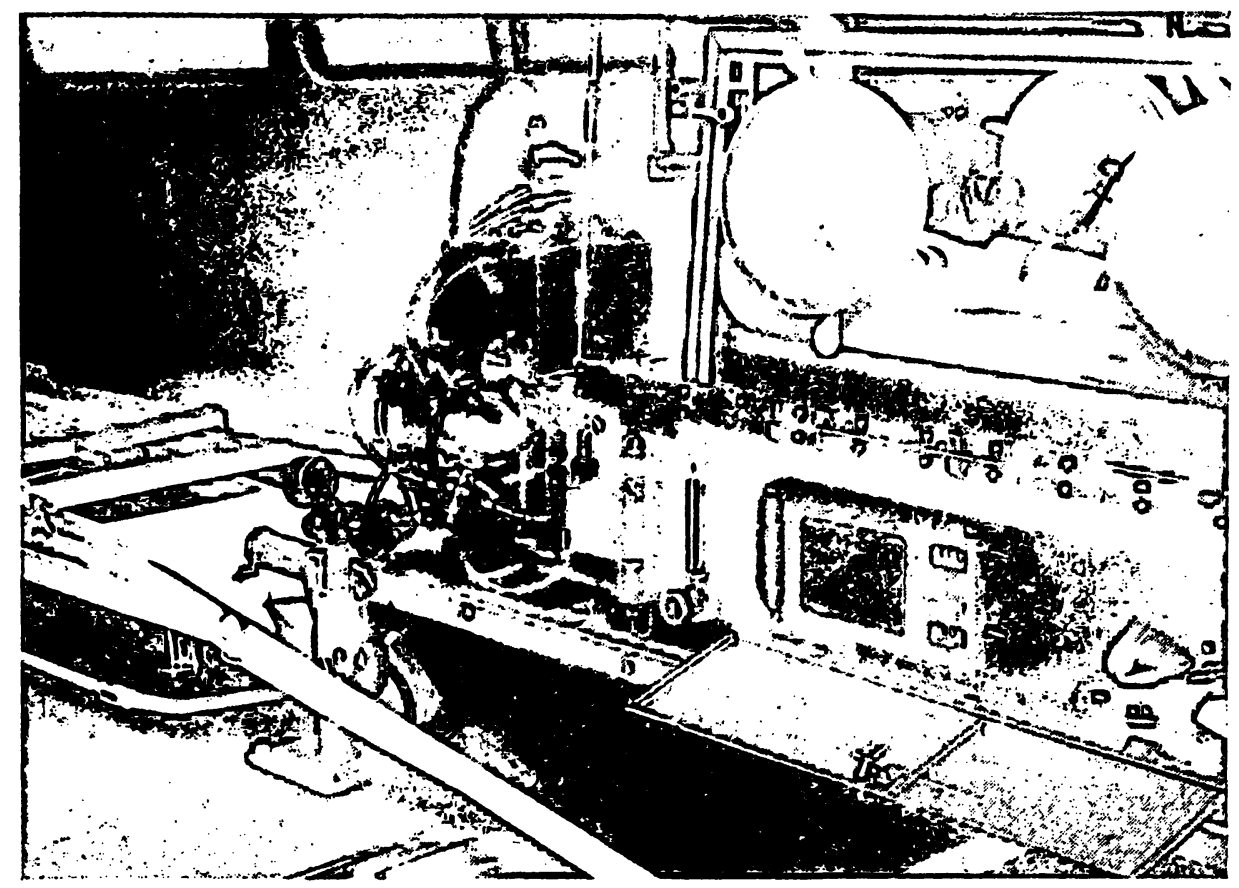

ambulance, it is quite understandable that this prerequisite has little chance of realization. Our transport incubator (see Figs. 1 and 3) with its plexiglass hood allows for immediate recognition of respiratory disturbances or changes in skin color.

The inside temperature of the incubator may also be checked and regulated at any time. To make easier the detection of cardiac arrhythmias, the addition of a battery-powered ECG monitor with oscilloscope and auditory signal has proven itself useful. Minor procedures on the child may be carried out through the adjustable cuffed portals on the sides, or the sliding door at the head end of the incubator. More extensive procedures such as intubation are performed with the child pulled out and covered. For this purpose we have cut out a hinged door on the functional side of the incubator and have placed the mattress on a sliding tray.

\subsubsection{Independent power supply:}

Three-liter oxygen tanks are always taken with the incubator, making it independent from a central gas supply for approximately 30 minutes even though it has 4 oxygen outlets. This is necessary to bridge the gap between delivery room, ambulance and the intensive care unit. A greater problem is the availability of heat or thermal energy. The manufacturers of the incubator have not yet made it possible to adapt the present heater for conversion from 220 volt alternating current to direct current and there by battery power. The thermal energy stored in heat rods and a water tank is sufficient for going from one wall plug to the other in the clinic grounds.

The entire resuscitation unit is securely mounted upon a standard stretcher frame (see Figs. 1 and 3). Two orderlies or ambulance personnel can easily carry the entire apparatus by the 4 retractable hand grips. To facilitate the transport through the halls and elevators of the clinic, the stretcher frame is placed upon a wagon with pneumatic tires. The entire transport unit has an allotted place on the ward of the Children's Clinic. It is constantly plugged in and is routinely desinfected and serviced.

\subsection{Means of transport}

\subsubsection{Spacious ambulance:}

The Berlin Fire Department, which as a large institution has considerable experience in emergency service, has two commonly used ambulance types at its disposal, namely the VW bus and the small Mercedes truck. The first was excluded from the outset because it could not accommodate an incubator with these dimensions. The Mercedes was suitable in terms of the space it provided, but unfortunately it always had to be rearranged before it could be used to 
transport the incubator. This rearrangement consisted of setting a gasoline-powered generator for 220 volt alternating current on the back bumper, bolting it down firmly and establishing a cable plug connection between the motor and the body of the truck. This process is timeconsuming in an emergency.

This drawback could only be overcome by the acquisition of a special ambulance with a firmly built-in generator. Having made this "expensive" decision, it then actually became possible to design an emergency vehicle that met all of the technical specifications for transport in terms of external and internal safety, and at the same time allowed for monitoring and treatment of the tiny patient in a generously spacious rroom.

\subsubsection{The Ford-Transit 130 ambulance; internal and external safety (Fig. 2):}

a) As an official emergency vehicle, it carries all of the special equipment characteristic of the Fire Department, such as luminous color, siren, flashing blue light and 2-way radio, etc. This allows for rapid transit through heavy traffic.

b) The vehicle has an elevated ceiling so that one may stand while carrying out procedures on the child after the ambulance has come to a halt.

c) The accompanying medical personnel are seated during the trip to the maternity hospital on the side bench to the left and front with safety belts fastened.

d) In the patient area there is a special lift table that can be raised or lowered to the desired height by means of a simple foot pedal.

e) The entire resuscitation unit mounted on a standard stretcher frame can be rolled in over a ramp and onto the U-shaped guide tracks of the lift table (Figs. 2, 3). A self-activating snap lock assures safe securing of the unit.

f) The profile frame itself is spring-suspended over the crossed legs of the lift table, and thereby aids in damping the bumps in the road.

g) During the trip back to the children's clinic, the observer sits upon a folding seat with back rest. The seat is built into the wall of the side cabinet, and is exactly at the level of the hinged door of the incubator (Fig. 2). In this manner, the child and all of the supportive equipment are within immediate reach.

\subsubsection{Power reserve (Fig. 4):}

The generator for 220 volt alternating current is permanently located behind a hinged door in a

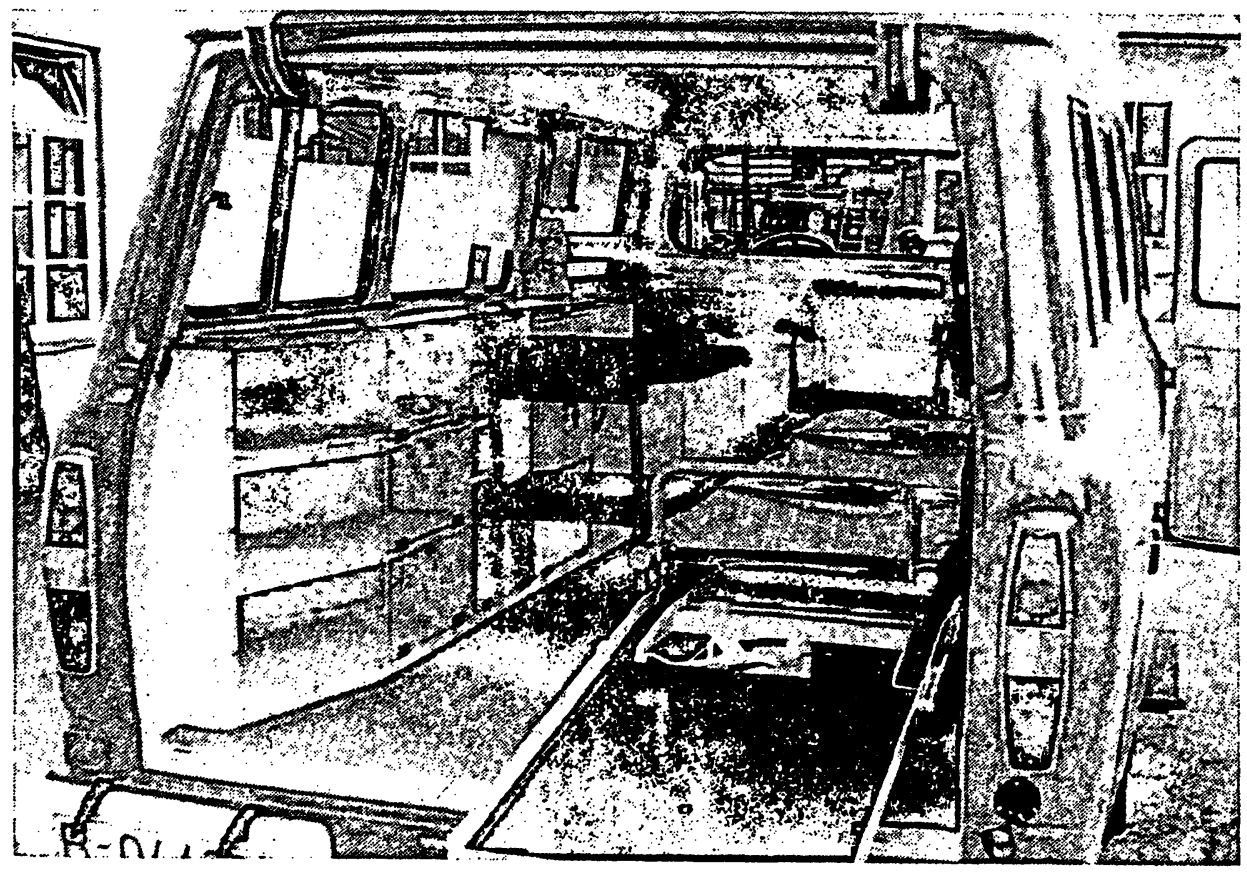

Fig. 2. The basic arrangement of the patient area of the mobile unit 


\section{a)}

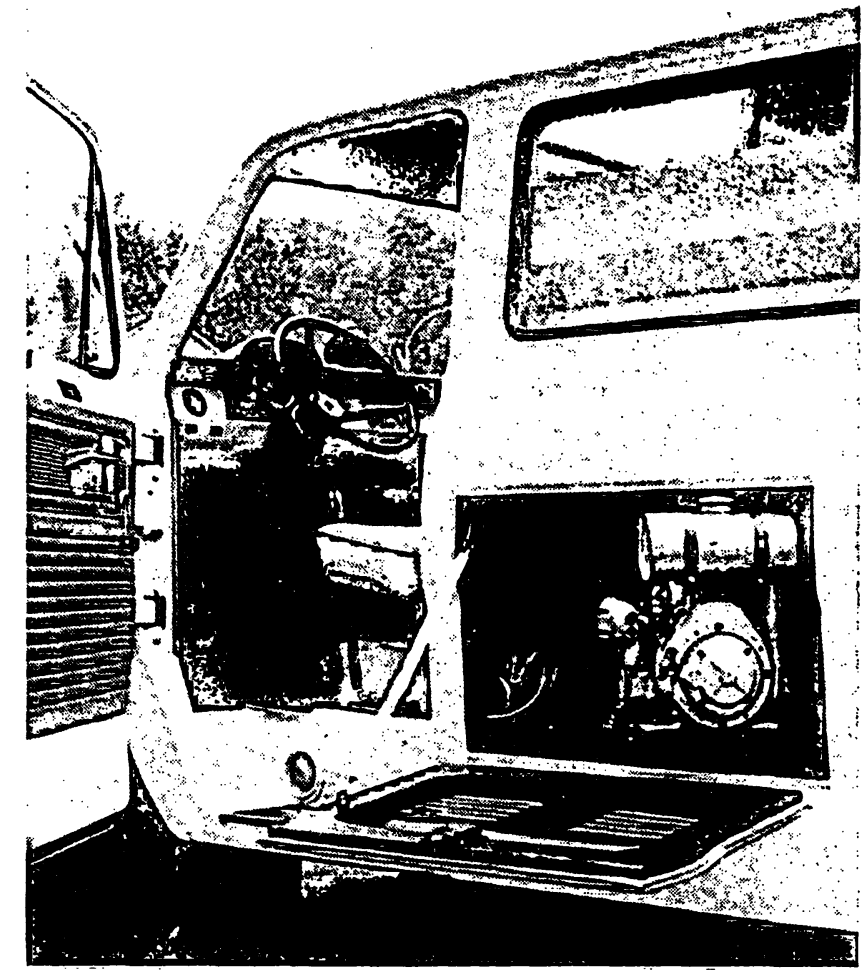

Fig. 4. 220 volt generator in the side compartment of the ambulance.

side compartment of the ambulance. It requires starting with a pull rope. Oxygen is obtained from two wall outlets supplied by a 10 -liter tank. The generator of the ambulance itself runs the electric motor for the hydropneumatic lift arrangement of the table and a water pump for the hand wash basin, and it supplies the current

\section{Summary}

Newborns with ongoing disturbances in vital functions following primary resuscitation in the delivery room often must be transferred over long distances to pediatric or neonatal intensive care units. Continuation of therapy, monitoring and nursing care once initiated may prove to be quite difficult and even dangerous for both patient and accompanying medical personnel during a hasty trip with an inadequately secured narrow transport incubator.

Drawing on prior experience gained both in Germany and other countries, the physicians and technicians of the Children's Clinic of the Free University of Berlin in conjunction with the Fire Department of the City of West for indirect, overhead and operative lights in the patient area of the ambulance.

\subsection{Transport personnel}

This system of transport is effective only when a team capable of handling special situations quickly and competently is permanently present. Physicians and nurses are therefore appropriately recruited from the personnel of the newborn intensive care unit. For them to be ready to undertake on average 2 trips in 3 days means an additional duty. The problem of a constantly available driver was solved by integrating the special ambulance service into that of a nearby depot of the Fire Department.

\section{Practical execution of a transport run}

We intend to have a physician and nurse with intensive care incubator and emergency kit promptly available in cases of high risk delivery. This means that in particular situations they should actually be present in the delivery room before completion of the birth. This can be achieved in high risk cases by prior telephone notification. When assistance in the resuscitation is desired, we are able to carry this out with familiar instruments and in the completely heat-protected environment of the incubator. Thereafter, preparations for optimal transport can be made very calmly. The return trip itself can proceed in an especially careful and steady manner. Well trained personnel and the technical equipment of the ambulance provide a good deal of safety in case of emergency in transit.

Berlin, developed an emergency transport service for newborns that meets the prerequisites of perinatal emergencies with regards to personnel staffing, equipment outfitting and purposeful organization.

The transport incubator used was a converted standard nursery incubator from the DRAEger company. The spacious plexiglass hood allows for continuous observation. The previously present openings in the incubator are satisfactory for carrying out minor procedures on the child. An additional hinged door cut out on the functional side of the incubator creatcs free access for major procedures such as intubation. The mattress on which the baby rests 
may be slid out on guide rails through this side door. Arranged around the incubator are a suction apparatus, outlets for humidified oxygen, an infusion stand as well as a respirator for assisted ventilation (BIRD-Mark 8). A smaller battery-powered ECG monitor, which is located in a side compartment of the incubator, makes monitoring of cardiac rate and rhythm easy. This complete resuscitation and artificial respiration unit is securely mounted upon a standard-sized stretcher frame, and may be carried by hand grips or transported within the Children's Clinic upon a wagon with pneumatic tires. A supply of thermal energy in the heat rods and a water tank as well as oxygen in a 3-liter tank provide a limited energy reserve.

The search for an appropriate means of transportation ended with the Ford Transit 130 ambulance. The procurement and medical-technical outfitting of the ambulance was carried out by the Children's Clinic, whereas the Berlin Fire Department provides the service and maintenance of the vehicle. The ambulance is marked by its color and warning lights as an emergency vehicle, and is thereby capable of traveling through city traffic with speed and safety. The most essential piece of equipment provided in the standing room patient area consists of a maneuverable and spring-suspended lift table, upon whose guide tracks the resuscitation unit can be rolled in and out. An automatic snap lock guarantees the absolute securing of the incubator. A gasoline-powered generator stored in a side wall compartment (Fig. 4) provides 220 volt alternating current for the heating element of the incubator. Oxygen may be obtained from 2 wall outlets supplied by 10 liter oxygen tanks.

A 24-hour perinatal emergency service was established for regular accompaniment of newborns on their way to our unit; it consists of a physician and a nurse from the intensive care ward. For the duration of any transport run, ward coverage is provided by a team on emergency call schedule. This continual readiness enables us in the majority of perinatal emergency situations to be available on location in time, even before the completion of the delivery, with the mobile resuscitation unit. The asphyxtic newborn can immediately be transferred to our incubator, and there, under protective warmth and with familiar intruments and equipment, may be resuscitated. Preparations for optimal transport and the trip back itself may thus be carried out without the strain of being pressed for time.

Keywords: Ambulance, emergency health service, intensive care unit, postnatal care.

\section{Zusammenfassung}

\section{Rettungswagen mit Wiederbelebungseinheit für Risiko-Neugeborene}

In ihren vitalen Funktionen gestörte Neugeborene müssen nach Abschluß der primären Reanimation im Kreißsaal oft über erhebliche Entfernungen auf eine pädiatrische Intensivstation verlegt werden. Bei rascher Fahrt und mangelhafter Fixierung enger, unübersichtlicher Transportinkubatoren gestalten sich das Fortführen der eingeleiteten Therapie, die Überwachung und Pflege des $\mathrm{Pa}$ tienten durch das Begleitpersonal vielfach recht schwierig und risikoreich.

Fußend auf bereits vorhandenen Erfahrungen im In- und Ausland haben Ärzte und Techniker der Kinderklinik der Freien Universität Berlin in Zusammenarbeit mit der Feuerwehr der Stadt Berlin West einen Rettungsdienst für Neugeborene entwickelt, der hinsichtlich personeller Besetzung, apparativer Ausstattung und zweckdienlicher Organisation im Rettungswesen den Erfordernissen eines perinatalen Notfalls angemessen erscheint.

Als Transportinkubator findet ein von uns veränderter Inkubator der Firma Draeger Verwendung. Die getäumige Plexiglashaube erlaubt eine kontinuierliche Überwachung. Die vorhandenen Öffnungen genügen zur Durchführung kleinerer Eingriffe am Kind; eine zusätzlich eingeschnittene Klapptür an der Funktionsseite des Inkubators schafft freien Zugang z. B. für eine Intubation. Die Liegefläche läßt sich auf einer Schienenführung durch die Türöffnung teilweise herausfahren. Um den Inkubator herum sind eine Absaugevorrichtung, eine
Steckdose zum Anschluß eines Sauerstoffsprudlers, ein Infusionsständer sow̌ie ein Gerät zur maschinellen Beatmung (BIRD-Mark 8) angeordnet. Ein kleiner, batteriebetriebener EKG-Monitor, der als Einschub im Inkubatorblock untergebracht ist, erleichtert die Herzüberwachung. Diese vollständige Wiederbelebungsund Beatmungseinheit ist auf einer DIN-genormten Krankentrage fest montiert und kann mit Hilfe der Tragengriffe bzw. in der Kinderklinik auf einem luftbereiften Wagen transportiert werden. Die in Heizstäben und im Wassertank gespeicherte Wärmeenergie sowie die in einer Halterung stets mitgeführte Sauerstoffflasche mit 31 Inhalt sichern einen zeitlich begrenzten Energievorrat.

Auf der Suche nach dem geeigneten Transportauto bot sich der Rettungswagen ForD Transit 130 an. Anschaffung und medizinisch-technische Ausstattungen besorgten die Mitarbeiter der Kinderklinik, während sich die Berliner Feuerwehr für den rettungsmäßigen Einsatz sowie für die Instandhaltung des Fahrzeugs zur Verfügung stellte. Der Wagen ist durch Farbe und Warneinrichtungen als Rettungswagen gekennzeichnet und läßt sich dadurch schnell und sicher durch den Großstadtverkehr fahren. Die wesentlichste Einrichtung des mannshohen Krankenraumes besteht in einem leichtgängigen und gefederten Hubtisch, in dessen Laufschienen dié Wiederbelebungseinheit auf ihren Rollen einzufahren ist. Ein automatischer Schnapprerschluß garantiert eine absolut sichere Arretierung des Inkubators. Ein benzinbetriebener Stromerzeuger in der seitlichen Bordwand (Abb. 4) liefert 220 Volt Wechselstrom für das Heizaggregat des Inku- 
bators. Sauerstoff kann über 2 Wandsteckdosen aus einer 10 l-Flasche entnommen werden.

Zur regelmäßigen Transportbegleitung wurde ein perinataler Notfalldienst über 24 Stunden eingerichtet, bestehend aus einem Arzt und einer Schwester der Intensivstation. Für die Zeit des Einsatzes übernimmt ein in Rufbereitschaft befindliches Team die Stationsaufgaben. Diese Dauerbereitschaft versetzt uns in die Lage, in der Mehrzahl der perinatalen Notfallsituationen rechtzeitig, u. U. schon vor Beendigung der Geburt, mit der mobilen Wiederbelebungs- und Transporteinheit zur Stelle zu sein. Das asphyktische Neugeborene kann sofort in den Inkubator übernommen und dort bei vollem Wärmeschutz (mit vertrautem Instrumentarium) reanimiert werden. Die Vorbereitungen für einen optimalen Transport können ebenso wie die Rückfahrt selbst völlig frei von schädlichem Zeitdruck vonstatten gehen.

Schlüsselwörter: Reanimation des Neugeborenen, Verlegung des Neugeborenen, Transportinkubator.

\section{Résumé}

\section{Ambulance spéciale pour les soins néonataux}

A la suite de mesures primaires de réanimation à la maternité, des nouveaux-nés atteints de désordres des fonctions vitales, doivent souvent être transférés de loin dans un service hospitalier spécialisé pour les soins néonataux. Etant donné que les couveuses portables sont étroites et difficiles à fixer pendant un tel transport rapide, l'observation des bébés et la poursuite d'une thérapie quelconque déja commencée sont assez difficiles et pleines de risques inconnus.

Profitant d'expériences d'institutions semblables en Allemagne et ailleurs, des médecins et des techniciens du Service de Pédiatrie de l'Université Libre de Berlin ont institué, en collaboration avec le Corps des Pompiers de Berlin-Ouest, un service de secours pour des nouveaux-nés, qui est mieux préparé pour un transport d'urgence, grâce à un équipement meilleur et une organisation centrale.

Le transport du nouveau-né est effectué dans une couveuse DraEger un peu modifiée. Son grand dôme transparent permet une observation optimale de l'enfant transporté. Ses accès normaux suffisent pour les manipulations regulières du nourrisson. Au côté fonctionnel de la couveuse, a été ajouté un autre accès qui est assez grand pour permettre l'intubation du nouveau-né. Pour cette manoeuvre, tout le matelas, avec l'enfant allongé, peut être facilement tiré hors de l'incubateur. Autour de la couveuse ont été placés un appareil de succion, un ballon d'oxygène, des installations électriques, un moyen pour suspendre des bouteilles à infusions, ainsi qu'un respirateur (BIRD Mark 8). Un moniteur électrocardiographique, installé dans la couveuse même, facilite la surveillance du malade. Cet équipemenr, suffisant pour une réanimation rapide du nouveau-né transporté, est fixé en bloc sur un brancard et peut être facilement. transporté, soit porté par deux personnes, soit sur un charriot spécial. L'énergie thermique nécessaire, accumulée dans un appareil de chauffage et dans un réservoir d'eau, ainsi que la réserve d'oxygène de cette unité de secours suffisent pour une opération limitée pendant le transport de la salle d'accouchement à l'ambulance.

Comme véhicule nous nous servons d'une Ford Transit 130. L'installation médico-technique a été proposée et surveillée par les néonatologistes, tandis que le Service des Pompiers est responsable aussi bien du contrôle de la voiture et de sa disponibilité permanente que du transport même. En tant que moyen de transport d'urgence, cette ambulance spéciale se remarque par sa couleur et ses installations d'alarme optique et acoustique qui facilitent son passage au milieu du traffic urbain.

L'installation la plus importante de l'ambulance, dont la hauteur permet au personnel accompagnant d'entrer debout, est une table mobile pour l'équipement de réanimation déja décrit, qui est faite pour pouvoir facilement border et déborder. Une fixation automatique empêche la couveuse de bouger pendant le voyage. Une source d'énergie à gasoline dans la paroi latérale de la voiture donne un courant électrique de 220 Volts pour le système de chauffage de la couveuse. L'oxygène dérive d'un réservoir changeable de 10 litres.

Une équipe de secours périnatale, toujours prête à pouvoir aller chercher les nouveaux-nés dans les maternités, a été formée. L'équipe de l'ambulance se compose d'un médecin et d'une infirmière du service périnatologique. Pendant la durée du transport, une autre équipe les remplace dans le service même.

L'ambulance de secours nous donne la possibilité d'être près du nouveau-né malade aussitôt que possible, parfois avant que l'accouchement soit accompli. Le bébé est mis dans la couveuse sans délai et peut être réanimé rapidement dans des conditions optimales et à la bonne température. Plus tard, les péparations pour le transport et le voyage même peuvent être faites avec toute précaution nécessaire, car le nouveau-né est déjà soigné.

Mots clés: Ambulances, service publique d'urgence, service hospitalier spécial pour les soins néonataux, surveillance postnatale.

\section{Acknowledgements}

We are obliged to the staff of the Berlin Fire Department for ideal cooperation and technical advice in many cases. 


\section{Bibliography}

[1] Barrie, H.: A Mobile Neonatal Care Unit. In: Huntingford, P. J., R. W. BeARD, F. E. Hytten and J. W. Scopes: Perinatal Medicine, Second European Congress of Perinatal Medicine, London 1970, S. Karger, Basel 1971

[2] Lemburg, P., E. A. Stemmann: Die technische Ausrüstung der pädiatrischen Intensiv-Station. Archiv für Kinderheilkunde, Beiheft 63 (1971)

[3] v. Loewenich, V., D. Berg: Planung und Organisation einer interdisziplinären Intensivbehandlungseinheit für Neugeborene. In: OPDERBECKE, H. W.: Anaesthesiologie und Wiederbelebung, Band 33: Planung, Organisation und Einrichtung von Inten- sivbehandlungseinheiten am Krankenhaus, S. 116, Springer, Berlin-Heidelberg-New York 1969

[4] MaUs, H.: Tragbares automatisches Beatmungsgerät für Neugeborene (in Verbindung mit dem TransportInkubator zur Verlegung von Neugeborenen in die Kinderklinik). Kurzdemonstration auf dem 3. Deutschen Kongreß für Perinatale Medizin, Berlin 1970

[5] SchweIKaRT, J.: Diskussionsbeitrag anläßlich der 68. Tagung der Deutschen Gesellschaft für Kinderheilkunde, Wiesbaden 1970

[6] Silverman, W. A.: Interview in „Neues aus Bonn“, Februar 1969, Medizintechnische Information der Firma Heinen $\mathrm{GmbH}$, Bonn

Dr. H.-D. Frank

Freie Universität Berlin

Kaiserin Auguste Victoria Haus

Heubnerweg 6

D-1000 Berlin 19

Germany 